ORIENTAL JOURNAL OF CHEMISTRY

An International Open Free Access, Peer Reviewed Research Journal

www.orientjchem.org
ISSN: 0970-020 X

CODEN: OJCHEG

2014, Vol. 30, No. (4):

Pg. 1933-1940

\title{
Development and Validation of Stability Indicating UV and RP-HPLC Method for The Estimation of Flupritine maleate in Bulk and Formulations
}

\author{
D. GOWRISANKAR ${ }^{1}$ and N.MALLIKARJUNA RAO ${ }^{2 *}$ \\ ${ }^{1}$ Department of Pharmaceutical Analysis and Quality Assurance, University College \\ of Pharmaceutical Sciences, Andhra University, Visakhapatnam, India. \\ 2Department of Pharmaceutical Sciences, Jawaharlal Nehru Technological University, Kakinada, India \\ ${ }^{*}$ Corresponding author E-mail: mallimpharmmba@gmail.com \\ http://dx.doi.org/10.13005/ojc/300455 \\ (Received: August 26, 2014; Accepted: October 06, 2014)

\begin{abstract}
The objective of the study was to develop stability indicating UV spectroscopy and RP-HPLC method for the estimation of flupritine maleate in bulk and marketed tablets. Chromatographic separation was achieved on Agilent Eclipse C18, $150 \times 4.6 \mathrm{~mm}$, 3u with mobile phase consisting of Buffer $(1 \mathrm{ml}$ OPA and $1 \mathrm{mI}$ TEA in $1000 \mathrm{ml}$ water and $\mathrm{pH}$ was adjusted to 3 with dilute OPA) and Methanol are taken in $50: 50 \% \mathrm{v} / \mathrm{v}$. The effluent was monitored at $246 \mathrm{~nm}$. A sharp peak was observed at $4.0 \mathrm{~min}$. UV Spectrophotometric method was performed at $250 \mathrm{~nm}$ using methanol as the solvent. $R^{2}=0.999$ for HPLC method and $R^{2}=0.998$ for UV Spectrophotometric method. The method was validated as per $\mathrm{ICH}$ guidelines with linearity, precision, accuracy, robustness, ruggedness and specificity. Statistical analysis showed that both the methods were precise, accurate, sensitive, and Stability indicating can be used for the routine analysis of flupritine economically in bulk and commercial formulations.
\end{abstract}

Key words: Flupritine maleate, RP-HPLC, UV-Spectrophotometric, Method development and validation, Degradation, ICH guidelines.

\section{INTRODUCTION}

Flupritine acts as a centrally acting non opioid analgesic ${ }^{1}$. Chemically it is amino pyridine derivative with the chemical name of ethyl 2-amino6-[(4 fluorobenzyl) amino] pyridin-3-yl carbamate maleat ${ }^{2}$. Flupritine was noted for its neuroprotective properties and also investigated for use in Creutzfeldt-Jakob disease, Alzheimer's disease, and multiple sclerosis. Literature review reveals that various analytical methods like UVSpectrophotometry ${ }^{3-4}$, HPLC $^{5-7}$ have been 
developed However nostability indicating UV methods are reported but one stability indicating HPLC method $^{8}$ was reported for the estimation of flupritine maleate Hence, an attempt was madeto develop simple, accurate and precise stability indicating UV and RPHPLC methods for the estimation of flupritine maleate in pure and their marketed formulations.

\section{EXPERIMENTAL}

\section{Materials and methods}

LABINDIA-3000+ UV-Visible double beam spectrophotometer with a fixed slit width $1 \mathrm{~nm}$ and $1 \mathrm{~cm}$ matched quartz cells was used for all the spectral measurements.Alliance WATERS e 2695 HPLC with UV, VISIBLE-2489 \& PDA-2998 Detector. All reagents used were of analytical reagent (AR) grade. HPLC grade methanol and water was used throughout analysis. Flupritine sample was kindly provided by Sun pharmaceuticals Ltd.

\section{Chromatogrphic conditions and mobile phase in HPLC}

Chromatographic separation was achieved on Agilent Eclipse C18, $150 \times 4.6 \mathrm{~mm}, 3 \mu$. Flow rate was maintained at $1.0 \mathrm{ml} / \mathrm{min}$ with $30^{\circ} \mathrm{C}$ column temperature. The detection was monitored at $246 \mathrm{~nm}$ and the run time was 8 minutes. The volume of injection loop was $10 \mu \mathrm{l}$ prior to injection of the drug solution. To $1000 \mathrm{ml}$ of HPLC grade water $1 \mathrm{ml}$ of orthophosphoric acid and $1 \mathrm{ml}$ of TEA were added and the $\mathrm{pH}$ adjusted to 3 with dilute OPA solution. The mobile contains Buffer and Methanol in the ratio of $60: 40 \% \mathrm{v} / \mathrm{v}$, filtered through $0.45 \mu$ membrane filter and sonicated for 20 minutes to degas. Water and Methanol(50:50) was used as diluent.

\section{Optimized conditions in UV}

Methanol is used as diluent. $250 \mathrm{~nm}$ was selected as detection wavelength.

\section{Preparation of solutions in HPLC Preparation of standard solution}

Accurately Weighed and transferred $10 \mathrm{mg}$ of flupritine maleate working Standard into a $10 \mathrm{ml}$ clean dry volumetric flask, and $7 \mathrm{ml}$ of HPLC grade Water was added, sonicated for 5 minutes and make up to the final volume with diluent. (Fig.2)

\section{Preparation of sample solution}

20 tablets were weighed and crushed into powder, weight equivalent to 1 tablet was calculated. 5 tablets powder weight was transferred into a 200 $\mathrm{mL}$ volumetric flask, $150 \mathrm{~mL}$ of diluent added and sonicated for $25 \mathrm{~min}$, further the volume made up with diluent and filtered. From the filtered solution $4.0 \mathrm{ml}$ was pipetted out into a $100 \mathrm{ml}$ volumetric flask and made up to $100 \mathrm{ml}$ with diluent. The $\%$ assay was found to be $100 \%$.

\section{Preparation of solutions in UV Preparation of standard solution}

Accurately weigh and transfer $10 \mathrm{mg}$ of flupritine Working standard into a $10 \mathrm{~mL}$ volumetric flask add about $7 \mathrm{~mL}$ of Diluent and sonicated to dissolve it completely and madethe volume up to the mark with the same solvent (Stock solution). Further pipette $0.3 \mathrm{ml}$ of the flupritine stock solution into a $10 \mathrm{ml}$ volumetric flask and dilute up to the mark with diluent. (Fig.3)

\section{Preparation of Sample preparation}

Accurately weigh and transfer equivalent to10 $\mathrm{mg}$ of Tablet powder Fpmt Working standard into a10 mL volumetric flask add about $7 \mathrm{~mL}$ of Diluent and sonicated to dissolve it completely and made volume up to the mark with the same solvent (Stock solution). Further pipette $0.3 \mathrm{ml}$ of the flupritine stock solution into a $10 \mathrm{ml}$ volumetric flask and dilute up to the mark with diluent. The $\%$ assay was found to be $100 \%$.

\section{Validation of the method}

Validation of the optimized method was performed according to the ICH Q2 (B) guidelines ${ }^{9-10}$.

\section{System suitability studies}

The system suitability test was carried out on freshly prepared stock solution of flupritine to check various parameters such as column efficiency, tailing factor and number of theoretical and presented in Table 1. The values obtained were demonstrated the suitability of the system for the analysis of the drug. System suitability parameter may fall within $2 \%$ standard deviation range during routine performance of the method. 


\section{Linearity}

For the HPLC methodfor the determination of linearity, prepared standard solution at five different concentration levels. The method was found to be linear in the range of 50 to $150 \%$ of target assay concentration i.e. 200 to $600 \mu \mathrm{g} / \mathrm{ml}$. peak areas were recorded and calibration curve was plotted by plotting peak areas on $\mathrm{y}$ axis and concentration on $\mathrm{x}$ axis. The calibration curve was shown in fig.3and the results are presented in table 2.In UV the method was found to be linear in the range of 50 to $175 \%$ of target assay concentration. I.e. 10 to $35 \mu \mathrm{g} / \mathrm{ml}$ measured the absorbances of the above levels at 250nm Plotted a graph of peak area versus concentration (on $\mathrm{X}$-axis concentration and on Y-axis Peak area) and calculate the correlation coefficient. The calibration curve was shown in fig. 4 and the results are presented in table 3.

\section{Method precision (intra and inter day)}

The repeatability of the analytical method under normal operational conditions was verified by injecting assay preparationssix times individuallyand calculated the \% RSD. The same was performed on different day also. And the \% RSD values for intraday and interday precision were based on the mean and standard deviations. The $\%$ RSD was found to be less than $1 \%$ by UV and less than $2 \%$ by HPLC, indicating that the method was sufficiently precise; the results are shown in table 4.

\section{Accuracy or recovery}

Accuracy is the percent of the analyte recovered by assay from a known added amount. This study is mainly useful in order to check the accuracy of the developed method and to study the interference of the formulation additives. For the measurement of accuracy data from nine determinations over three concentration levels i.e. 50\%, 100\% and $150 \%$ were determined. The results are presented in table 5.

\section{Robustness}

Robustness of the method was verified by altering individually the chromatographic conditions like mobile phase composition $(10 \%)$, flow rate $( \pm 0.2 \mathrm{ml})$, column temperature $\left( \pm 5^{\circ} \mathrm{C}\right)$, etc.it was observed that no much variation in system suitability parameters even after these small delibral changes.These results proved that the developed method was robust.In UV method the wave length was varied at $248 \mathrm{~nm}$ to $252 \mathrm{~nm}$. On evaluation of the above results, it can be concluded that the variation in wave length affected the method significantly. Hence it indicates that the method is robust even by change in the wave length.

\section{Forced degradation studies}

The International Conference on Harmonization (ICH) guideline entitled stability testing of new drug substances and products requires that stress testing be carried out to elucidate the inherent stability characteristics of the active substance. The aim of this work was to perform the stress degradation studies on theflupritine using the proposed methodForced degradation of the flupritine maleate drug substance was performed under acid, alkaline, peroxide, thermal, photolytic and hydrolysis stress conditions. The procedure and results were summarized in the table $6 \& 7$.

\section{RESULTS AND DISCUSSION}

The developed methods for estimation of flupritine maleate were found to be accurate, simple and precise. The simplicity and ease of the developed methods lie in using Methanol as solvent.

The linearity of both HPLC and UV methods showed excellent correlation coefficient of 0.999 .

In precision studythe\% RSD was found to be less than $1 \%$ by UV and less than $2 \%$ by HPLC, indicating that the method was sufficiently precise. Both methods showed good recovery and the recovery values are found between 98 to $101 \%$ and $\%$ RSD was found to be less than $1 \%$ indicating accuracy of the method. The method was found to be robust because system suitability was passed even though deliberal changes were made in the developed HPLC and UV methods. In degradation studies it was observed that purity threshold value greater than the purity angle in each condition value it indicates the noninterference of the excipients, degradants with the analyte peak. 
Table 1: System suitability

\begin{tabular}{lcccc}
\hline Injection & RT & Peak Area & USP plate count & USP Tailing \\
\hline 1 & 4.986 & 5229276 & 3832 & 1.7 \\
2 & 4.956 & 5245400 & 3837 & 1.7 \\
3 & 4.912 & 5236608 & 3842 & 1.7 \\
4 & 4.863 & 2546067 & 3839 & 1.7 \\
5 & 4.833 & 5197315 & 3762 & 1.7 \\
6 & 4.802 & 5010547 & 3962 & 1.7 \\
Mean & 4.892 & 5194202 & 3845.6 & 1.683 \\
SD & 0.071769 & 91737.14 & - & - \\
$\% S D$ & 1.467 & 1.766 & - & - \\
\hline
\end{tabular}

Table 2: Results of Linearity by HPLC

\begin{tabular}{lcc}
\hline Linearity level & Concentration & Area \\
\hline $\mathrm{L} 1-50 \%$ & $200 \mu \mathrm{g} / \mathrm{ml}$ & 2707744 \\
$\mathrm{~L} 2-7575 \%$ & $300 \mu \mathrm{g} / \mathrm{ml}$ & 4120178 \\
$\mathrm{~L} 3-100 \%$ & $400 \mu \mathrm{g} / \mathrm{ml}$ & 5664215 \\
$\mathrm{~L} 4-125 \%$ & $500 \mu \mathrm{g} / \mathrm{ml}$ & 7052773 \\
$\mathrm{~L} 5-150 \%$ & $600 \mu \mathrm{g} / \mathrm{ml}$ & 8632105 \\
\hline
\end{tabular}

Table 3: Results of Linearity by UV spectroscopy

\begin{tabular}{cccc}
\hline S. No & Linearity Level & Concentration & Absorbance \\
\hline 1 & I $(50 \%)$ & $10 \mu \mathrm{g} / \mathrm{ml}$ & 0.326 \\
2 & II $(70 \%)$ & $15 \mu \mathrm{g} / \mathrm{ml}$ & 0.456 \\
3 & III $(100 \%)$ & $20 \mu \mathrm{g} / \mathrm{ml}$ & 0.6 \\
4 & IV $(125 \%)$ & $25 \mu \mathrm{g} / \mathrm{ml}$ & 0.719 \\
5 & V $(150 \%)$ & $30 \mu \mathrm{g} / \mathrm{ml}$ & 0.883 \\
6 & VI $(175 \%)$ & $35 \mu \mathrm{g} / \mathrm{ml}$ & 1.01 \\
Correlation coefficient & 0.999 & & \\
\hline
\end{tabular}

Table 4: Results of Precision by HPLC and UV

\begin{tabular}{|c|c|c|c|c|}
\hline \multirow{2}{*}{$\begin{array}{l}\text { Sample } \\
\text { No. }\end{array}$} & \multicolumn{2}{|c|}{ HPLC } & \multicolumn{2}{|c|}{ UV spectroscopy } \\
\hline & $\begin{array}{l}\text { Intraday } \\
\text { \% Assay }\end{array}$ & $\begin{array}{l}\text { Interday } \\
\% \text { Assay }\end{array}$ & $\begin{array}{l}\text { Intraday } \\
\% \text { Assay }\end{array}$ & $\begin{array}{l}\text { Interday } \\
\% \text { Assay }\end{array}$ \\
\hline 1 & 100.3 & 100.2 & 99.4 & 99.6 \\
\hline 2 & 100.6 & 98.8 & 99.4 & 99.6 \\
\hline 3 & 100.4 & 100.7 & 99.4 & 99.6 \\
\hline 4 & 100.6 & 99.1 & 99.4 & 99.6 \\
\hline 5 & 99.7 & 101.0 & 99.6 & 99.8 \\
\hline 6 & 96.1 & 100.6 & 99.4 & 99.8 \\
\hline Mean & 99.6 & 100.1 & 99.4 & 99.7 \\
\hline RSD (\%) & 1.76 & 0.89 & 0.1 & 0.1 \\
\hline
\end{tabular}


Table 5: Results of Recovery by HPLC and UV

\begin{tabular}{lcccccc}
\hline $\begin{array}{l}\text { S. } \\
\text { No }\end{array}$ & $\begin{array}{c}\text { Level of } \\
\text { Recovery (\%) }\end{array}$ & $\begin{array}{c}\text { Recovery } \\
(\%) \mathbf{N = 3}\end{array}$ & $\begin{array}{c}\text { \%R.S.D. } \\
\mathbf{N = 3}\end{array}$ & $\begin{array}{c}\text { Level of } \\
\text { Recovery (\%) }\end{array}$ & $\begin{array}{c}\text { Recovery } \\
\text { (\%) } \mathbf{N = 3}\end{array}$ & $\begin{array}{c}\text { \%R.S.D } \\
\mathbf{N}=\mathbf{3}\end{array}$ \\
\hline 1 & $50 \%$ & $99.4 \%$ & 0.3 & $50 \%$ & $101.3 \%$ & 0.3 \\
2 & $100 \%$ & $100.1 \%$ & 0.3 & $100 \%$ & $99.6 \%$ & 0.2 \\
3 & $150 \%$ & $98.6 \%$ & 0.2 & $150 \%$ & 98.7 & 0.1 \\
\hline
\end{tabular}

Table 6: Summary of degradation studies byHPLC

\begin{tabular}{|c|c|c|c|c|c|}
\hline \multirow[t]{2}{*}{ Mode of degradation } & \multirow[t]{2}{*}{ Conditions } & \multirow{2}{*}{$\begin{array}{c}\text { Assay } \\
\text { (mgl } \\
\text { tablet) }\end{array}$} & \multicolumn{3}{|c|}{ Flupritine maleate } \\
\hline & & & $\begin{array}{l}\text { \%Degradation } \\
\text { w.r.t. control }\end{array}$ & $\begin{array}{l}\text { Purity } \\
\text { angle T }\end{array}$ & $\begin{array}{c}\text { Purity } \\
\text { Threshold }\end{array}$ \\
\hline Control & No treatment & 398.2 & - & - & - \\
\hline Acid degradation $5 \mathrm{~N} \mathrm{HCl}$ & $40^{\circ} \mathrm{C} / 5 \mathrm{~min}$ & 369.2 & 7.30 & 0.131 & 0.289 \\
\hline Alkali degradation $1 \mathrm{~N} \mathrm{NaOH}$ & $80^{\circ} \mathrm{C} / 1 \mathrm{hr}$ & 360.76 & 9.40 & 0.153 & 0.293 \\
\hline Peroxide degradation $30 \% \mathrm{~W} / \mathrm{V} \mathrm{H}_{2} \mathrm{O}_{2}$ & $80^{\circ} \mathrm{C} / 10 \mathrm{~min}$ & 293.76 & 26.20 & 0.209 & 0.296 \\
\hline Thermal degradation & $105^{\circ} \mathrm{C} / 72 \mathrm{hrs}$ & 376.32 & 5.50 & 0.195 & 0.306 \\
\hline Photolytic degradation & UV/72hrs & 331.56 & 16.70 & 0.176 & 0.304 \\
\hline Humidity degradation & $25^{\circ} \mathrm{C} / 90 \% \mathrm{RH} / 72 \mathrm{hrs}$ & 395.08 & 0.80 & 0.146 & 0.289 \\
\hline
\end{tabular}

Table 7: Summary of degradation studies by UV

\begin{tabular}{|c|c|c|c|c|c|}
\hline Type & Conditions & $\begin{array}{c}\text { Sample } \\
\text { Absorbance }\end{array}$ & $\begin{array}{c}\% \\
\text { Assay }\end{array}$ & $\begin{array}{c}\% \\
\text { DEG }\end{array}$ & Observation \\
\hline \multicolumn{6}{|l|}{ Acid degradation } \\
\hline $\begin{array}{l}5 \mathrm{~N} \mathrm{HCl} \\
\text { Alkali degradation } 1\end{array}$ & $40^{\circ} \mathrm{C} / 5 \mathrm{~min}$ & 0.513 & 85.2 & 14.80 & degraded \\
\hline $\begin{array}{l}\mathrm{N} \mathrm{NaOH} \\
\text { Peroxide degradation }\end{array}$ & $80^{\circ} \mathrm{C} / 1 \mathrm{hr}$ & 0.511 & 84.7 & 15.30 & degraded \\
\hline $30 \%$ W/V H2O2 & $80^{\circ} \mathrm{C} / 10$ mins & 0.538 & 89.3 & $11 \%$ & degraded \\
\hline Thermal degradation & $105^{\circ} \mathrm{C} / 72 \mathrm{hrs}$ & 0.565 & 93.9 & $7 \%$ & degraded \\
\hline Photolytic degradation & UV/72 hrs & 0.506 & 84 & $16 \%$ & degraded \\
\hline Humidity degradation & $25^{\circ} \mathrm{C} / 90 \% \mathrm{RH} / 72 \mathrm{hrs}$ & 0.567 & 94 & $6 \%$ & degraded \\
\hline
\end{tabular}<smiles>CCOC(=O)Nc1ccc(NCc2ccc(F)cc2)nc1N</smiles>

Fig. 1: Chemical structure of flupritine maleate 


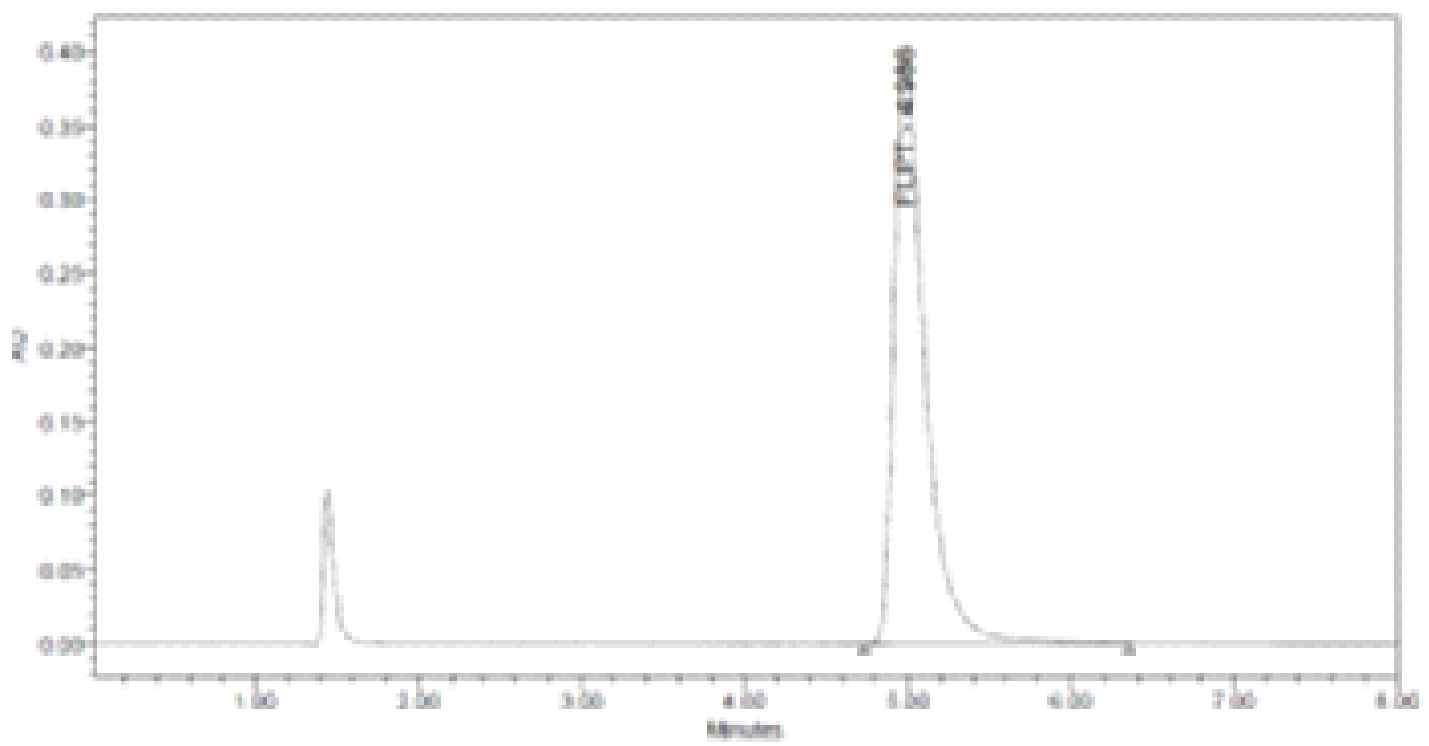

Fig. 2: Standard chromatogram of Flupritine maleate

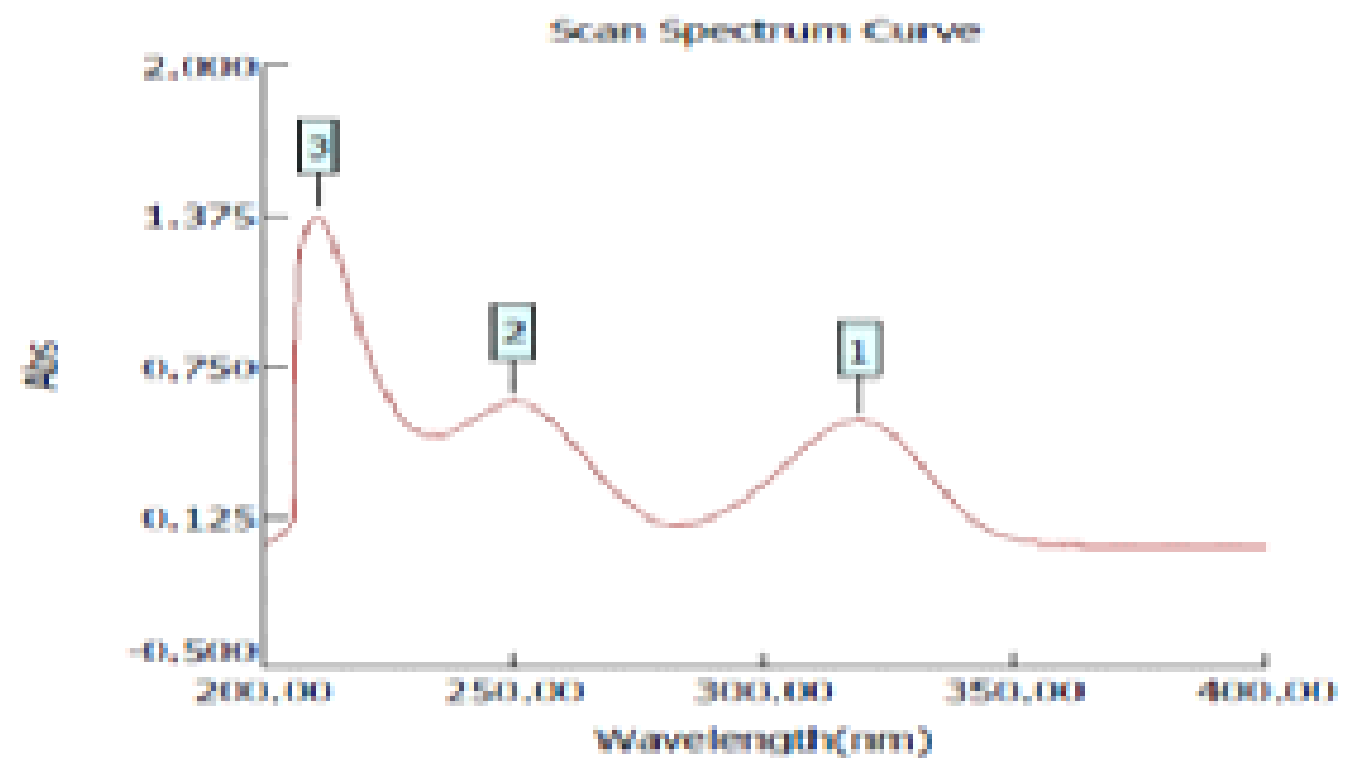

\begin{tabular}{|c|c|c|c|}
\hline 1 & Prouk & 319 пи & 10,521 \\
\hline$y$ & Prak & 25и,ти & Itring \\
\hline 1 & Pratk & 211.141 & 1.37 \\
\hline
\end{tabular}

Fig. 3: Tpyical chromatogram of standard 


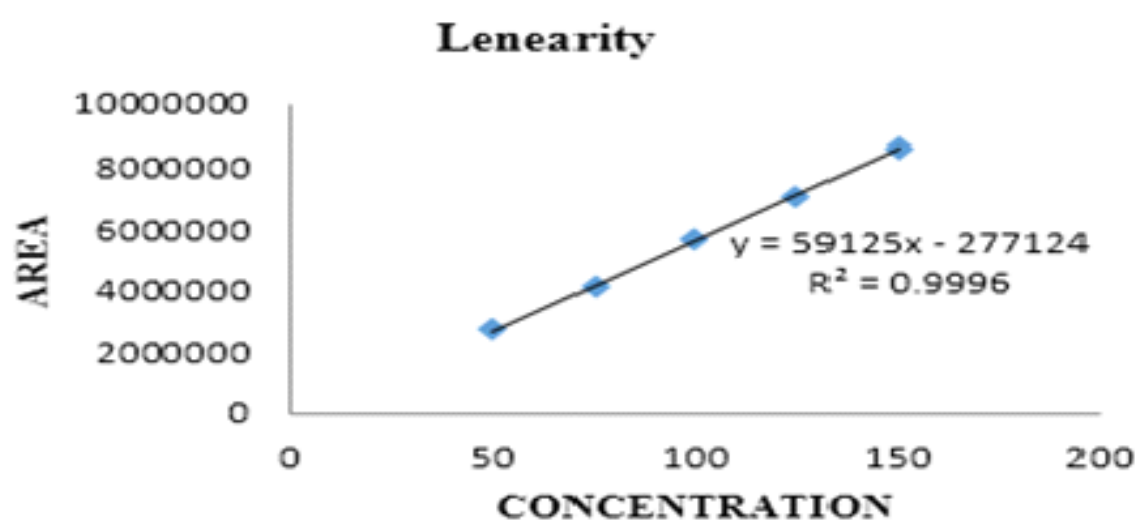

Fig. 4: Calibration curve by HPLC

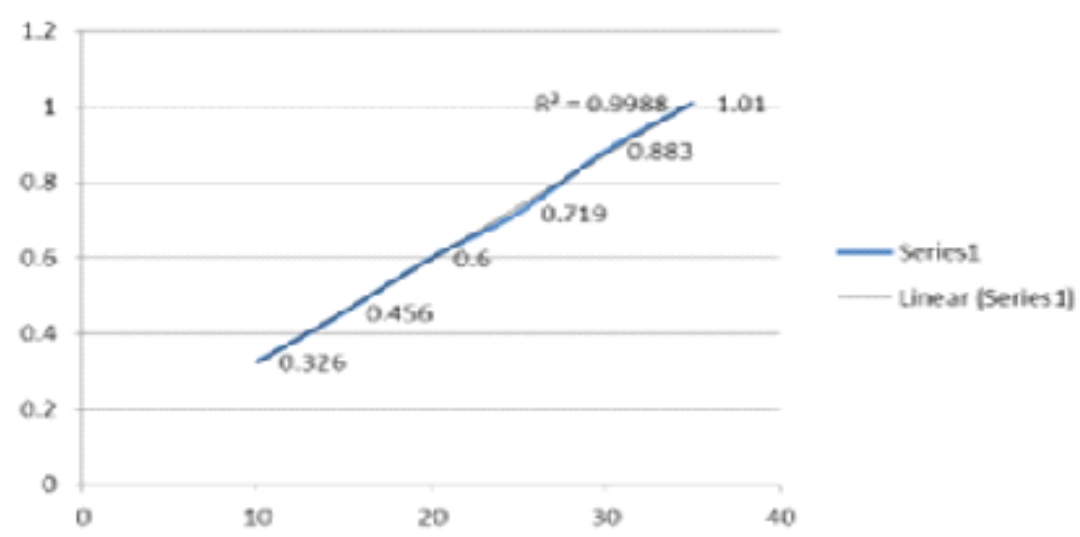

Fig. 5: Calibration curve by UV

\section{CONCLUSION}

The developed methods are able to analyze the commercial formulations economically.

\section{REFERENCES}

1. Devulder J. Flupirtine in pain management: pharmacological properties and clinical use. CNS Drugs. 2010; 24(10):867-881.

2. Neil OJM. The Merck Index, an Encyclopedia of Chemicals Drug and Biologicals,. Eds, 14th Edn., Merck Research Laboratories, Division of Merck and Co. Inc., White House Station, NJ. 2006:717.

3. Shah U, Kavad M and Raval M. Development and validation of UV spectrophotometric method for estimation of Paracetamol and Flupirtine maleate in bulk and pharmaceutical dosage form. International Journal of Pharm Tech Research. 2013; 5(3):1007-1013.

4. Amal Dand Aneesh TP. Method development and validation for the estimation of Flupirtine maleate in bulk and pharmaceutical dosage form by UV spectrophotometry. International Research Journal of Pharmacy. 2011;2(12):179-182.

5. Zhang D, Song $X$ and Su J. Isolation, 
identification and characterization of novel process-related impurities in Flupirtine maleate. Journal of Pharmaceutical and Biomedical Analysis. 2014; 90:27-34.

6. Lalitha KV, Murali Mohan G, Ravindra Reddy J, Vinod Kumar K and Alekhya A. RP-HPLC method development and validation for the simultaneous estimation of Paracetamol and Flupirtine maleate in pharmaceutical dosage. Journal of Scientific and Innovative Research. 2013; 2(3):634-641.

7. Wang $\mathrm{H}$, Zhang $\mathrm{Y}$ and Nie L. Determination of Flupirtine maleate capsules by RP-HPLC. Qilu Pharmaceutical Affairs.2010; 10:23-25.
8.

B. Mohan Gandhi, A. Lakshmana Rao and J. Venkateswara Rao a novel stability indicating $r p$-hplc method for the estimation of flupirtine in pharmaceutical dosage forms. International journal of pharmaceutical, chemical and biological sciences2014, 4(2), 208-218.

9. $\mathrm{ICH}$ Harmonised Tripartite Guideline, Validation of analytical procedures: Text and methodology, Q2 (R1), International Conference on Harmonization. 2005:1-13.

10. $\mathrm{ICH}$ Harmonised Tripartite Guideline, Stability Testing of New Drug Substances and Products, Q1A (R2), International Conference on Harmonization.2003:1-18. 